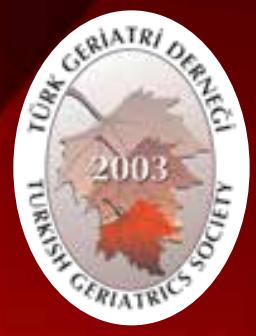

Turkish Journal of Geriatrics

DOI: $10.31086 /$ tjgeri.2019.94

2019;22 (2):205-213

- Ramadan ÖZMANEVRA ${ }^{1}$

- Barış POLAT ${ }^{1}$ iD

- Deniz AYDIN² (D

\title{
ANALYSIS OF BILATERAL FEMORAL GEOMETRIC PARAMETERS IN 16 PATIENTS WITH ATYPICAL FEMORAL FRACTURES
}

\section{Abstract}

Introduction: This study aimed to investigate the associationbetween femoralgeometry and clinical features and to analyse the effect of bisphosphonate use on atypical femur fracture healing.

Materials and Method: Patients admitted with femoral shaft fractures were examined,and thosewhofulfilled the diagnostic criteria for atypical fractures according to the 2014-revised edition of the American Society for Bone and Mineral Research(ASBMR) were included in this study. Fracture localisation, inner and outer cortical thickness, lateral bowing and femur neck-shaft angle of both fractured and contralateral sides were measured. We analysed the correlations between demographics, clinical factors and radiographic features.

Results: Our study group comprised 14 females and 2 males. The mean age was 76.3 (range, 67-91) years. The mean follow-up period was 45.9 (range, 12-84) months. All the fractures were located on the femoral shaft. The mean duration of fracture union was 8 (range, 4-11) months. The outer cortical thickness of the fractured side was significantly greaterthan that of the contralateral side. No significant difference was observed between the inner corticalthickness of the fractured and contralateral sides. The lateral bowing of the fractured femoral shaft was significantly greater than that of the contralateral femur. A significant positive correlation was observed between the duration of bisphosphonate use and both fracture healing time and lateral bowing of the femoral shaft.

Conclusion: Long-term bisphosphonate usealtersthe femoralgeometry not only on the fractured side but also on the contralateral side and increases the fracture risk.

Keywords: Femoral fractures; Osteoporosis; Alendronate; Diphosphonates

CORRESPONDANCE

Ramadan ÖZMANEVRA

University of Kyrenia, Northern Cyprus, Orthopaedics and Traumatology, Girne TRNC.

Mobile: +905338635167

e-mail: rozmanevra@gmail.com

Received: 24/04/2019

Accepted: $02 / 07 / 2019$

University of Kyrenia, Northern Cyprus, Orthopaedics and Traumatology, Girne, TRNC. Near East University, Orthopaedics and Traumatology, Lefkoşa, TRNC.

\section{ARAŞTIRMA}

\section{ATIPIK FEMUR KIRIĞI OLAN 16 HASTANIN HER IKI TARAF FEMURLARININ GEOMETRIK PARAMETRELERININ DEĞERLENDIRILMESi}<smiles>[Os]</smiles>

Giriş: Bu çalışmada femur geometrisi ile klinik özellikler arasındaki ilişkiyi araştırmak ve bifosfonat kullanımınına tipik femur kıı̆̆ı iyileşmesi üzerindeki etkisini analiz etmek amaçlanmıştır.

Gereç ve Yöntem: Femoral şaft kırığı ile başvuran hastalar analiz edildi ve Amerikan Kemik ve Mineral Araştırmaları Derneği (ASBMR)'nin 2014'te revise edilmiş baskısına gore atipik kırıklar için tanı kriterlerini karşılayan hastalar çalışmaya dahil edildi. Kırık lokalizasyonu, iç ve dış korteksin kalınlığı, lateral eğilme ve hem kırık hem de karşı tarafların femur boyun-cisim açıları ölçüldü. Demografik, klinik faktörler ve radyografik özellikler arasındaki korelasyonlar analiz edildi.

Bulgular: Çalışma grubumuz 14 kadın ve 2 erkekten oluşmaktadır. Ortalama yaş 76.3 (dağılım, 67-91) idi. Ortalama takip süresi 45.9 (dağılım, 12-84) aydı. Tüm kırıklar femur şaftı üzerinde idi. Ortalama kaynama süresi 8 (4-11) ay idi. Kırık tarafın dış korteksin kalınlığı kontralateral taraftan anlamlı derecede yüksekti. Kırık tarafın iç korteksinin kalınlığı kontralateral taraftan anlamlı derecede farklı değildi. Kırık femur şaftının lateral eğimi, kontralateral femurdan anlamlı derecede yüksekti. Bisfosfonat kullanım süresi ile hem kırık kaynama süresi hem de femur şaftının lateral eğilmesi arasında anlamlı bir pozitif korelasyon gözlendi.

Sonuç: Uzun vadeli BFS kullanımı femur geometrisini sadece kırık tarafında değil kontralateral tarafta da değiştirir ve kırılma riskini arttırır.

Anahtar sözcükler: Femur kırıkları; Osteoporoz; Alendronat; Bifosfonat 


\section{INTRODUCTION}

Osteoporosis is a skeletal disorder characterised by low bone density resulting inmicrostructure disorders that can increase fracture susceptibility (1). Osteoporosis has a higher prevalence among older adults. Notably, treatment of osteoporosis-related fractures can be expensive (2). Bisphosphonates (BPs) are widely used as therapy to efficiently treat and prevent fractures in patients with osteoporosis. Furthermore, they are often used as the first line of treatment for osteoporosisaccording to the current evidence-based guidelines (3). Moreover, BPsare used in the treatment of Paget's disease, metastatic bone disease and multiple myeloma.

Several large clinical trials have revealed the reliability and tolerability of BPs (4). However, postmarketing reports and epidemiological studies have reported some rare and potentially graveadverse effects associated with the long-term BPuse, such as dyspepsia, nausea, muscular pain, osteonecrosis of the jaw and atrial fibrillation (5). Becauseof theadverse effectsof BPs, despite the primary use of $\mathrm{BPs}$ to prevent osteoporosis-related fractures, a paradoxicalassociationbetween BPs and atypical femoral fractures (AFFs) was first demonstrated in 2008 (6). Several reports have suggested a possible association between BP use and AFFs (7-12).

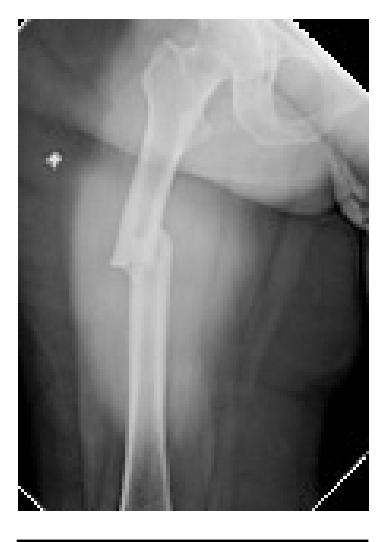

Figure 1. BP-related fracture of the femur shaft.

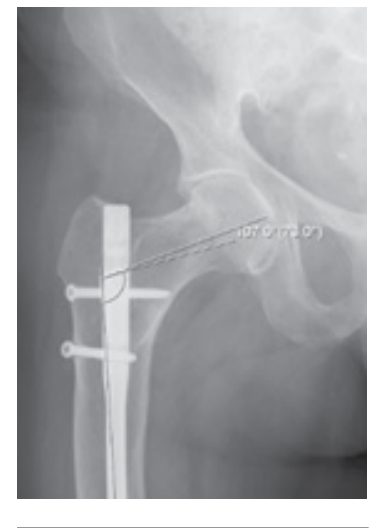

Figure 2. Measurement of femur neck-shaft angle.

The American Society for Bone and Mineral Research (ASBMR) defined the diagnostic criteria for AFFs in 2010 (13), and this has recently garnered interest. In 2014, the updated diagnostic criteria were published. AFF is diagnosed based on subtrochanteric or femoral shaft location and the presence of at least the following four or five major criteria: minimal trauma, fracture originating at the lateral cortex and being substantially transverse, complete fractures extending through both cortices, localised periosteal or endosteal cortical thickening and minimal comminution. Diagnosis excludes minor criteria; however, it includesincreased cortical thickness of the femoral diaphysis, bilaterality, a prodrome of thigh or groin pain and delayed fracture healing (14).

Few studies have investigated the association between AFFs and femoral geometry. Jang et al. reported the association between bowing and cortical thickness (15). A study by Starr et al. concluded that a decrease in the femoral neck-shaft angle and an increase in lateral bowing increased the risk of AFF because of the tensile stress applied to the lateral femoral cortex (16).

Therefore, our study included both clinical features and radiological measurements, including femoralgeometry. This study aimed to investigate

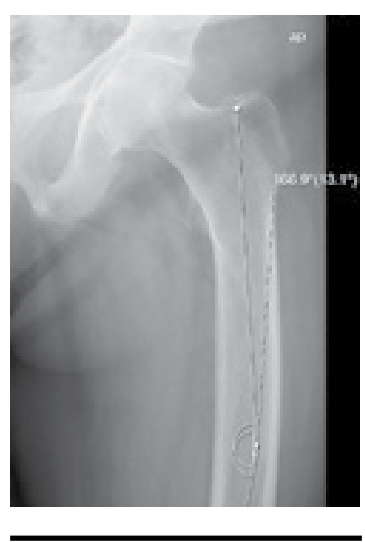

Figure 3. Method of lateral bowing measurement.

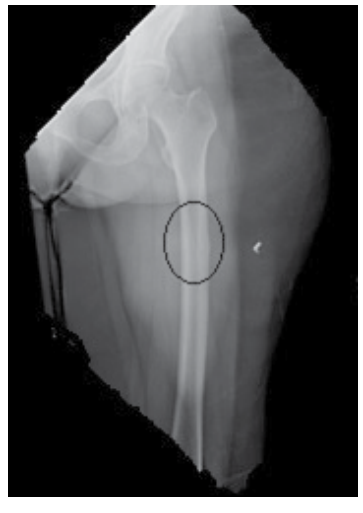

Figure 4. Lateral cortical thickness. 
Table 1. Demographic features of the patients.

\begin{tabular}{|c|c|c|c|c|}
\hline \multicolumn{2}{|l|}{ Variable } & Min.-Max & Median & Mean \pm sd \\
\hline \multicolumn{2}{|l|}{ Age } & $67.0-91.0$ & 74.0 & $76.3 \pm 7.4$ \\
\hline \multirow{2}{*}{ Gender } & Female & & 14 & $87.5 \%$ \\
\hline & Male & & 2 & $12.5 \%$ \\
\hline $\begin{array}{l}\text { Fracture location } \\
\text { (Femur) }\end{array}$ & Shaft & & 16 & $100.0 \%$ \\
\hline \multirow{2}{*}{ Operation type } & IMN & & 12 & $75.0 \%$ \\
\hline & Plate & & 4 & $25.0 \%$ \\
\hline \multirow{2}{*}{$\begin{array}{l}\text { Type of } \\
\text { Bisphosphonate }\end{array}$} & Alendronate & & 12 & $75.0 \%$ \\
\hline & Risedronate & & 4 & $25.0 \%$ \\
\hline \multicolumn{2}{|c|}{ Duration of Bisphosphonate use (Year) } & $4.0-12.0$ & 7.0 & $7.1 \pm 2.3$ \\
\hline \multirow{2}{*}{ Supplement } & $\mathrm{Ca}$ & & 16 & $100.0 \%$ \\
\hline & D-Vit & & 16 & $100.0 \%$ \\
\hline \multicolumn{2}{|c|}{ Fracture healing time(months) } & $4.0-11.0$ & 8.0 & $7.9 \pm 1.8$ \\
\hline
\end{tabular}

the association between femoralgeometry and clinical features, alongwiththe effect of BPs on fracture healing.

\section{MATERIALS AND METHOD}

Patients admitted to a Level 1 Trauma Centre between January 2012 and January 2018 with femoral shaft fractures were analysed, and those who fulfilled the diagnostic criteria for atypical fractures according to the 2014-revised edition of the ASBMR were included in this study. Exclusion criteria were femoral fractures following high-energy trauma, patients who had previously undergone femoral surgery, patients whose BPuse duration was $<4$ years and thosewith inadequate radiographs that did not permit measurements. In total, 16 patients were included in this study. The patients' medical records and radiographs (pelvis anteroposterior andbilateral femur anteroposterior views) were examined retrospectively. Demographic data were collected, including patients' age, gender, BP use duration, type of surgery performed and type of BP used.

\section{Image analysis}

Calculations were independently performed by two orthopaedic surgeons according to the ASBMR. Fracture localisation, inner and outer cortical thickness, lateral bowing and femoral neckshaft angle of both the fractured and contralateral sides were measured (Figures 1-4).

The femoral neck-shaft angle was calculated and classifiedinto three groups: normal (between $\left.125^{\circ}-140^{\circ}\right)$, coxa valga $\left(>140^{\circ}\right)$ and coxa vara $\left(<125^{\circ}\right)$. The femoral bowing angle was described as the angulation between the proximal and distal quarters of the femoral diaphysis. We analysed the associations between demographics, clinical factors and radiographic features. 
Table 2. Measurements by the two orthopaedic surgeons.

\begin{tabular}{|c|c|c|c|c|c|c|c|}
\hline & \multicolumn{2}{|c|}{$\begin{array}{r}1^{\text {st }} \text { Orthopaedic } \\
\text { surgeon }\end{array}$} & \multicolumn{2}{|c|}{$\begin{array}{r}2^{\text {nd }} \text { Orthopaedic } \\
\text { surgeon }\end{array}$} & $p^{w}$ & $\begin{array}{r}r \text { (\%95 Confidence } \\
\text { Interval) }\end{array}$ & $p^{\prime c}$ \\
\hline \multicolumn{8}{|l|}{ Cortical thickness } \\
\hline Fractured side(outer) & $6.7 \pm 1.3$ & 7.0 & $6.7 \pm 1.3$ & 6.9 & 0.083 & $\begin{array}{r}0.9980 .995- \\
0.999\end{array}$ & 0.000 \\
\hline Fractured side (inner) & $5.7 \pm 1.3$ & 5.7 & $5.7 \pm 1.3$ & 5.7 & 0.285 & $\begin{array}{r}0.9970 .993- \\
0.999\end{array}$ & 0.000 \\
\hline Contralateral side (outer) & $5.7 \pm 0.8$ & 6.0 & $5.7 \pm 0.8$ & 6.0 & 0.083 & $\begin{array}{r}0.9960 .987- \\
0.999\end{array}$ & 0.000 \\
\hline Contralateral side (inner) & $5.9 \pm 1.7$ & 5.3 & $5.8 \pm 1.7$ & 5.3 & 0.083 & $\begin{array}{r}0.9980 .995- \\
0.999\end{array}$ & 0.000 \\
\hline \multicolumn{8}{|l|}{ Femur neck-shaft angle } \\
\hline Fractured side & $123.7 \pm 8.0$ & 121.5 & $123.7 \pm 8.0$ & 121.8 & 1.000 & $\begin{array}{r}0.9950 .985- \\
0.998\end{array}$ & 0.000 \\
\hline Contralateral side & $127.8 \pm 5.6$ & 127.0 & $127.8 \pm 5.2$ & 127.3 & 0.873 & $\begin{array}{r}0.9950 .985- \\
0.998\end{array}$ & 0.000 \\
\hline \multicolumn{8}{|l|}{ Lateral bowing } \\
\hline Fractured side & $6.7 \pm 3.2$ & 6.5 & $6.7 \pm 3.2$ & 6.4 & 0.282 & $\begin{array}{r}0.9990 .996- \\
1.000\end{array}$ & 0.000 \\
\hline Contralateral side & $6.0 \pm 2.7$ & 6.0 & $6.0 \pm 2.7$ & 6.1 & 0.475 & $\begin{array}{r}0.9990 .998- \\
1.000 \\
\end{array}$ & 0.000 \\
\hline Nail diameter & $11.8 \pm 1.2$ & 12.0 & $11.8 \pm 1.2$ & 12.0 & 1.000 & $\begin{array}{r}1.0001 .000- \\
1.000 \\
\end{array}$ & 0.000 \\
\hline Medulla diameter & $15.1 \pm 3.0$ & 14.5 & $15.1 \pm 2.8$ & 14.4 & 0.822 & $\begin{array}{r}0.9930 .975- \\
0.998\end{array}$ & 0.000 \\
\hline
\end{tabular}

$\mathbf{p}^{\mathrm{w}}$ Wilcoxon test / $\mathbf{p}^{\mathrm{IC}}$ Intraclass Correlation

\section{Statistical analysis}

The mean, standard deviation, median lowest, highest, frequency and ratio values of the descriptive statistics were used. The distribution of the variables was measured using the Kolmogorov-Smirnov test. The Wilcoxon test was used to analyse dependent quantitative data. Correlation was analysed using the intra-class correlation analysis. The statistical analysis was performed using the SPSS 22.0 programme.

\section{Ethical approval}

The study was approved by the Ethics Committee of the University of Kyrenia (Northern Cyprus) (RY2018-28).

\section{RESULTS}

Our study group comprised 14 females and 2 males. The mean age was 76.3 (range, 67-91) years. The mean follow-up period was 45.9 (range, 12-84) months. All the fractures were located on the femoral shaft. Twelve of these fractures were treated using anintramedullary nail (IMN), and the other fourwere treated using plate fixation. 
In one of the IMN surgeries, the distal onethird ofthe femoral shaft was fractured; however, the surgerywas completed by pushing the nail forwards and distal to the iatrogenic fracture line withoutadditionalintervention.

Twelve and four patients were using alendronate and risedronate, respectively. The BP useduration ranged from a minimum of 4 to a maximum of 12 years. All patients used calcium and vitamin D supplementation.

The mean duration of fracture union was 8 (range, 4-11) months (Table 1). The coxa vara was present in nine patients, whereasseven patients had a normal femoral neck-shaft angle. On the contralateral side, eight coxa vara and eight normal hips were detected.

Furthermore, no significant difference was observed between the measurements conducted by the two orthopaedic surgeons, and a significant correlation was observed (Table 2).

The outer cortical thickness of the fractured side was significantly higher than that of the contralateral side $(p<0.05)$ (Figure 5). No significant difference was observed between the inner corticalthickness of the fractured and contralateral sides ( $p>0.05)$. The lateral bowing of the fractured femoral shaft was significantly greaterthan that of the contralateral femur $(p<0.05)$ (Table3). A significant $(p<0.05)$ positive correlation was observed between fracture healing time and BP useduration (Table 4). Furthermore, a significant $(p<0.05)$ positive correlation was observed between the lateral bowing of the fracture side shaft and BPuse duration.

\section{DISCUSSION}

Osteoporosis remains a health concern for the growing elderlypopulation.Long-term BPtherapy for treating patients with osteoporosis is associated with AFFs. An increasing number of reports have identified complete AFFsduring pre-and postoperative periods in patients using BPs (7-12). However, whetherBPs are the only cause of AFFs is yet unclear because some reports have identified AFFsthat are unrelated to BP use (17). AFFs have been frequently reported since 2005 (18), accounting for approximately $1 \%$ of all femoral fractures (19).

A study by Napoli et al. identified that women with thinner medial cortices were at a higher risk of subtrochanteric/diaphyseal femoral fracture. Moreover, they indicated that medial or total cortical thickness strongly correlated with fracture risk compared with the lateral cortical thickness (20). In our study, the outer corticalthickness of the fractured side was significantly greater than that of the contralateral side. However, no significant difference was observed between the inner cortical thickness of the fractured and contralateral sides.

Table 3. Comparison of the measurements between fractured and contralateral sides.

\begin{tabular}{|c|c|c|c|c|c|}
\hline & \multicolumn{2}{|c|}{ Fractured side } & \multicolumn{2}{|c|}{$2^{\text {nd }}$ Orthopaedic surgeon } & \multirow{2}{*}{$\mathbf{p}^{w}$} \\
\hline & mean \pm sd & median & mean \pm sd & median & \\
\hline Cortical thickness-outer cortex & $6.7 \pm 1.3$ & 7.0 & $5.7 \pm 0.8$ & 6.0 & 0.011 \\
\hline Cortical thickness-inner cortex & $5.7 \pm 1.3$ & 5.7 & $5.9 \pm 1.7$ & 5.3 & 0.469 \\
\hline Femur neck-shaft angle & $123.7 \pm 8.0$ & 121.5 & $127.8 \pm 5.6$ & 127.0 & 0.098 \\
\hline Lateral bowing of the femur & $6.7 \pm 3.2$ & 6.5 & $6.0 \pm 2.7$ & 6.0 & 0.028 \\
\hline
\end{tabular}

$\mathrm{p}^{\mathrm{w}}$ Wilcoxon test 
Our study observed coxa vara in $56 \%$ of fractured femurs and $50 \%$ of contralateral femurs on analysis ofBP-related anatomical changes. However, increased femoral lateral bowing was observed in all patients, and the degree of lateral bowing was positively correlated with BP use duration. Thecomputed tomography (CT)-based nonlinear finite element analysis results in the literature revealed that decreased femoral neck-shaft angle and increased lateral bowing can increase the tensile stress over the subtrochanteric area and femoral shaft, respectively (21). We believe that the increased stress results inthe thickening of the lateral femoral cortex and that the continuous load results in fatigue fractures. Furthermore, increased fragility may be associated with histological changes caused by long-term BP use.

Lloyd et al. examined bone tissue from women with AFFs and revealedthat long-term BP treatment degrades the fracture-resistance and strengthening mechanisms that are inherent to a healthy bone (22). The likely anatomical and histological changes inthe femur in a patient with long-term BP use should be considered perioperatively because of the iatrogenic fracture risk, particularly following IMN. Notably, we experienced an iatrogenic distal femoral fracture in one of our study patients treated with IMN.

We observedan increase in the outer corticalthickness and a decrease in the femoral neck-shaft angle in the bowing side. Coxa vara was detected in approximately half of the patients on both the fractured and contralateral sides. When the femoral neck-shaft angles were compared, no statistically significant difference was found between the fractured and contralateral sides. This finding may suggest that a decrease in the femoral neck-shaft angle in the contralateral femur may increase the fracture risk.

Narusel et al. investigated the effect of alendronate in a rat model and identified that alendronate did not prevent long bone fragility in an inactive rat model; they concluded that BP use may provide therapeutic benefit to individuals with osteoporosis whose daily activity is not limited (23). Most patients receiving BP therapy are elderly and have limited mobilisation. Therefore, Narusel et al. reported that long-term BP use in these patients may have a negative effect on long bone fragility (23). Notably, our study group consisted of inactive patients who were typically mobilised within their home.

However, when these fractures occur, prophylactic surgical treatment of the contralateralextremity is controversial. A recent study advocated that prophylactic surgical treatment is cost-effective in patients with more than one risk factor. The risk factors were determined to be Asian ethnicity, prodromal pain, coxa vara, femoral bowing, periosteal beaking and transverse radiolucent line (24). Furthermore, IMN, which is the gold standard forfemoral shaft fractures, is performed for AFFs. IMN is advantageous because it decreasesthe load on the lateral cortex compared with the plate fixation. Therefore, IMN is recommended by most authors. However, only 4 of 16 patients inour study groupunderwentplate fixation. Therefore, we could not adequately compare the results of plate fixation and IMN because ofthe inequality between the two groups.

The limitations of our study are its retrospective design, the small number of patients and the lack of bone densitometry and inactivity scores.

In conclusion, our study predicted that longterm BP use not only changes the femoralgeometry on the fractured side but also on the contralateral side and increases the fracture risk. Furthermore, we predicted that the delay in fracture union may be associated with BPuse duration and that the fracture union is affected by changes in the femoral geometry.

The increased intraoperative fracture risk and 
delayed union of AFFs in the elderly, inactive and non-expressive patients with long-term BPusemust be considered to facilitate successful diagnosis and treatment.

\section{Conflict of interest}

All authors declare that there is no conflict of interest regarding this work.

Table 4. Correlation between measurements and demographic features.

\begin{tabular}{|c|c|c|c|c|c|}
\hline \multicolumn{2}{|l|}{ Measurement parameter } & \multirow{2}{*}{$\begin{array}{l}\text { Age } \\
0.491 \\
\end{array}$} & \multirow{2}{*}{$\begin{array}{r}\begin{array}{r}\text { Duration of } \\
\text { Bisphosphonate } \\
\text { Use }\end{array} \\
0.549 \\
\end{array}$} & \multirow{2}{*}{$\begin{array}{r}\text { Fracture } \\
\text { Healing Time } \\
- \\
\end{array}$} & \multirow{2}{*}{$\begin{array}{r}\text { Medulla-Nail } \\
\text { thickness } \\
\text { difference }\end{array}$} \\
\hline & $r$ & & & & \\
\hline ridcture nedintig timite & p & 0.054 & 0.028 & - & 0.796 \\
\hline \multirow{2}{*}{ Medulla-Nail thickness difference } & $\mathbf{r}$ & -0.342 & -0.012 & 0.084 & - \\
\hline & $\mathbf{p}$ & 0.277 & 0.969 & 0.796 & - \\
\hline \multicolumn{6}{|l|}{ Cortical thickness } \\
\hline \multirow{2}{*}{ Fractured side-outer cortex } & $\mathbf{r}$ & -0.084 & -0.102 & 0.295 & 0.222 \\
\hline & $\mathbf{p}$ & 0.756 & 0.707 & 0.268 & 0.488 \\
\hline \multirow{2}{*}{ Contralateral side-outer cortex } & $\mathbf{r}$ & 0.146 & 0.076 & 0.537 & -0.374 \\
\hline & $\mathbf{p}$ & 0.602 & 0.788 & 0.039 & 0.257 \\
\hline \multirow{2}{*}{ Fractured side-inner cortex } & $\mathbf{r}$ & 0.269 & 0.047 & 0.376 & -0.251 \\
\hline & p & 0.333 & 0.868 & 0.167 & 0.457 \\
\hline \multirow{2}{*}{ Contralateral side-inner cortex } & $\mathbf{r}$ & 0.116 & -0.095 & 0.412 & -0.544 \\
\hline & $\mathbf{p}$ & 0.668 & 0.726 & 0.113 & 0.068 \\
\hline \multicolumn{6}{|l|}{ Femur neck-shaft angle } \\
\hline \multirow{2}{*}{ Fractured side } & $\mathbf{r}$ & -0.249 & -0.273 & -0.309 & -0.207 \\
\hline & p & 0.351 & 0.306 & 0.245 & 0.519 \\
\hline \multirow{2}{*}{ Contralateral side } & $\mathbf{r}$ & 0.028 & 0.188 & -0.125 & -0.274 \\
\hline & $p$ & 0.917 & 0.486 & 0.644 & 0.389 \\
\hline \multicolumn{6}{|l|}{ Lateral bowing of the femoral shaft } \\
\hline \multirow{2}{*}{ Fractured side } & $\mathbf{r}$ & 0.467 & 0.509 & 0.377 & 0.309 \\
\hline & $\mathbf{p}$ & 0.068 & 0.044 & 0.150 & 0.329 \\
\hline \multirow{2}{*}{ Contralateral side } & $\mathbf{r}$ & 0.393 & 0.386 & 0.299 & 0.405 \\
\hline & $p$ & 0.132 & 0.140 & 0.261 & 0.191 \\
\hline
\end{tabular}




\section{REFERENCES}

1. Consensus development conference: Diagnosis, prophylaxis, and treatment of osteoporosis. Am J Med 1993;94(6):646-50. (PMID:8506892).

2. Tatangelo G, Watts J, Lim K, et al. The cost of osteoporosis, osteopenia, and associated fractures in Australia in 2017. J Bone Miner Res 2019 Apr;34(4):616-25 (PMID:30615801).

3. Watts NB, Bilezikian JP, Camacho PM, et al. American Association of Clinical Endocrinologists Medical Guidelines for Clinical Practice for the diagnosis and treatment of postmenopausal osteoporosis. Endocr Pract 2010;16:1-37. (PMID:21224201).

4. Wells GA, Cranney A, Peterson J, et al. Alendronate for the primary and secondary prevention of osteoporotic fractures in postmenopausal women. Cochrane Database Syst Rev 2008;(1):CD001155. (PMID:18253985).

5. Schubert M, Klatte I, Linek W, et al. The Saxon bisphosphonate register - therapy and prevention of bisphosphonate-related osteonecrosis of the jaws. Oral Oncol 2012;48(4):349-54. (PMID:22130456).

6. Lenart BA, Lorich DG, Lane JM. Atypical fractures of the femoral diaphysis in postmenopausal women taking alendronate. N Engl J Med 2008;358(12):13046. (PMID:18354114).

7. Cheung RK, Leung KK, Lee KC, Chow TC. Sequential non-traumatic femoral shaft fractures in a patient on long-term alendronate. Hong Kong Med J 2007;13(6):485-89. (PMID:18057440)

8. Goh SK, Yang KY, Koh JS, et al. Subtrochanteric insufficiency fractures in patients on alendronate therapy: a caution. J Bone Joint Surg Br 2007;89(3):34953. (PMID:17356148).

9. Isaacs JD, Shidiak L, Harris IA, Szomor ZL. Femoral insufficiency fractures associated with prolonged bisphosphonate therapy. Clin Orthop Relat Res 2010;468(12):3384-92. (PMID:20809164).

10. Lenart BA, Neviaser AS, Lyman S, et al. Association of low-energy femoral fractures with prolonged bisphosphonate use: a case control study. Osteoporos Int 2009;20(8):1353-62. (PMID:19066707).

11. Odvina CV, Zerwekh JE, Rao DS, Maalouf $N$, Gottschalk FA, Pak CY. Severely suppressed bone turnover: a potential complication of alendronate therapy. J Clin Endocrinol Metab 2005;90(3):1294301. (PMID:15598694).
12. Sayed-Noor AS, Sjödén GO. Case reports: two femoral insufficiency fractures after long-term alendronate therapy. Clin Orthop Relat Res 2009;467(7):1921-6. (PMID:19198962).

13. Shane E, Burr D, Ebelling PR, et al. Atypical subtrochanteric and diaphyseal femoral fractures: report of a task force of the American Society for bone and mineral research. J Bone Miner Res 2010;25(11):2267-94. (PMID:20842676).

14. Shane E, Burr D, Abrahamsen B, et al. Atypical subtrochanteric and diaphyseal femoral fractures: second report of a task force of the American Society for Bone and Mineral Research. J Bone Miner Res 2014;29(1):1-23. (PMID:23712442).

15. Jang SP, Yeo I, So SY, et al. Atypical femoral shaft fractures in female bisphosphonate users were associated with an increased anterolateral femoral bow and a thicker lateral cortex: a case-control study. Biomed Res Int 2017;2017:5932496. (PMID:28459066).

16. Starr J, Tay YKD, Shane E. Current understanding of epidemiology, pathophysiology, and management of atypical femur fractures. Curr Osteoporos Rep 2018;16(4):519-29. (PMID:29951870).

17. Neviaser AS, Lane JM, Lenart BA, Edobor-Osula F, Lorich DG. Low-energy femoral shaft fractures associated with alendronate use. J Orthop Trauma 2008;22(5):346-50. (PMID:18448990).

18. Odvina CV, Zerwekh JE, Rao DS, Maalouf N, Gottschalk FA, Pak CY. Severely suppressed bone turnover: a potential complication of alendronate therapy. J Clin Endocrinol Metab 2005;90(3):1294301. (PMID:15598694).

19. Giusti A, Hamdy NA, Dekkers OM, Ramautar SR, Dijkstra S, Papapoulos SE. Atypical fractures and bisphosphonate therapy: a cohort study of patients with femoral fracture with radiographic adjudication of fracture site and features. Bone 2011;48(5):966-71. (PMID:21195812).

20. Napoli N, Jin J, Peters K, et al. Are Women with Thicker Cortices in the Femoral Shaft at Higher Risk of Subtrochanteric/Diaphyseal Fractures? The Study of Osteoporotic Fractures. J Clin Endocrinol Metab 2012;97(7):2414-22. (PMID:22547423).

21. Oh Y, Fujita K, Wakabayashi Y, Kurosa Y, Okawa A. Location of atypical femoral fracture can be determined by tensile stress distribution influenced by femoral bowing and neck-shaft angle: a CT- 
based nonlinear finite element analysis model for the assessment of femoral shaft loading stress. Injury 2017;48(12):2736-43. (PMID:28982480).

22. Lloyd AA, Gludovatz B, Riedel C, Luengo EA, Saiyed R. Atypical fracture with long-term bisphosphonate therapy is associated with altered cortical composition and reduced fracture resistance. Proc Natl Acad Sci USA 2017;114(33):8722-27. (PMID:28760963).

23. Narusel K, Uchidal K, Sutol M, et al. Alendronate does not prevent long bone fragility in an inactive rat model. J Bone Miner Metab 2016;34(6):615-26. (PMID:26475371). 